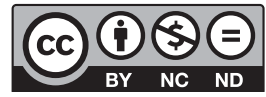

Estudos Teológicos foi licenciado com uma Licença Creative Commons Atribuição - NãoComercial - SemDerivados 3.0 Não Adaptada

http://dx.doi.org/10.22351/et.v60i2.4088

\title{
TEODICEIA, TEOPATIA E TEOREVOLTA: POR UMA CARTOGRAFIA DO MAL EM TEMPOS DE CORONAVÍRUS ${ }^{1}$
}

\author{
Theodicy, Theopathy and Theorevolt: \\ for a cartography of evil in times of coronavirus
}

\section{Alexandre Marques Cabral ${ }^{2}$ Edson Fernando de Almeida ${ }^{3}$}

\begin{abstract}
Resumo: O contexto atual suscita diferentes interpretações teológicas sobre a presença de Deus em meio ao sofrimento provocado pelo ciclo pandêmico que estamos vivendo. Tais interpretações procuram associar conceitos como Deus, sofrimento, mal, juízo, pecado e salvação. A teodiceia tem sido o paradigma interpretativo prevalente dessas relações ao afirmar metafisicamente a apatia, a onipotência e a bondade divinas em meio ao sofrimento. A teopatia representa uma segunda forma de interpretação teológica dessa relação ao propor um questionamento radical das afirmações metafísicas sobre a impassibilidade e onipotência divinas e a aproximação de Deus do sofrimento e da morte do inocente. Propomos que a inversão da onipotência operada pela teopatia, na forma da onipotência do amor, ainda opera na lógica da teodiceia e apontamos para a teorevolta como possibilidade de superação da teodiceia e transfiguração da noção de teopatia para pensar a experiência teológica de Deus e o mal em tempos de Covid-19.
\end{abstract}

Palavras-chave: Deus. Sofrimento. Mal. Teodiceia, teopatia e teorevolta.

Abstract: The current context raises different theological interpretations about the presence of God in the midst of the suffering caused by the pandemic cycle that we are experiencing. Such interpretations include concepts related to God, suffering, evil, judgment, sin and salvation. Theodicy has been the predominant interpretative paradigm of these metaphysically apathetic, omnipotent relationships and divine goodness amid suffering. A theopathy represents a second form of theological interpretation of this relationship with a proportion of radical questions about metaphysical statements about divine impassibility and omnipotence and God's approach to the suffering and death of the innocent. We propose that the inversion of omnipotence operated by theopathy, in the form of the omnipotence of love, still operates in the logic of theodicy and points to

1 O artigo foi recebido em 04 de julho de 2020 e aprovado em 18 de setembro de 2020 com base nas avaliações dos pareceristas ad hoc.

2 Doutor. UERJ - Universidade do Estado do Rio de Janeiro. E-mail: alxcbrl@yahoo.com.br

3 Doutor. UFJF - Universidade Federal de Juiz de Fora. E-mail: edsonfernandodealmeida@gmail.com 
a theorevolt as a possibility of overcoming theodicy and transfiguring the theopathy to think about the theological experience of God and evil in times of Covid-19.

Keywords: God. Suffering. Evil. Theodicy, theopathy and theorevolt.

\section{Introdução}

O presente artigo possui como objetivo central questionar a legitimidade do discurso teodiceico responder pelos contornos da experiência do mal no contexto do novo coronavírus. Uma das razões que justificam esse questionamento é a operacionalização teodiceica de alguns líderes religiosos brasileiros por ocasião da tematização da pandemia da Covid-19. Bastar levar em conta a narrativa do líder da Igreja Universal do Reino de Deus, Edir Macedo. Segundo ele, a pandemia possui face demoníaca. O caráter demoníaco da pandemia entrelaça o medo dos indivíduos e os interesses midiáticos e econômicos em promover o pânico da população mundial. Como ele mesmo afirmou para a revista Veja:

Satanás trabalha com medo, com o pavor, com a dúvida. Satanás apavora as pessoas. E quando as pessoas ficam apavoradas, ficam com medo ou com dúvida, as pessoas ficam fracas, débeis e suscetíveis. Qualquer ventinho que tiver é uma pneumonia para elas.

Em outro momento, o bispo afirma:

As pessoas estão apavoradas por algo que verdadeiramente não condiz com a realidade que a mídia tem jogado no ar, com o pavor que a mídia tem usado para levar as populações, as nações [a ficarem] apavoradas com respeito a esse vírus, o coronavírus. Por trás dessa campanha toda do coronavírus existe um interesse econômico, e onde há interesse econômico, aí tem ${ }^{4}$.

A conexão entre mal (Covid-19) e Satanás é uma das estratégias teodiceicas de imunização divina. Como veremos, a teodiceia consolida-se por meio de discursos que isentam não somente Deus da autoria do mal; ela torna a divindade imune a qualquer mal. Por isso, ou bem os seres humanos são causa do mal, ou bem o mal é causado por alguma personificação de si (demônio, diabo).

A simples inversão da imunidade ontológica divina assinalada pelas teodiceias e/ou mesmo a inscrição da divindade no âmbito da causalidade do mal (Deus seria produtor do mal) não parecem dar conta do problema. Isso aparece, como mostraremos, nas teopatias, que transformam Deus em vítima do mal, dele retirando a imunidade teodiceia. Contudo, os limites discursivos dessa compreensão se revelam tão logo percebemos que a simples inscrição divina na região do mal não somente despotencializa Deus, como o impede de não corroborar o mal que ele mesmo sofre. Ora,

4 O texto pode ser encontrado no site da revista Veja. Disponível em: <https:/veja.abril.com.br/religiao/ edir-macedo-dissemina-informacoes-falsas-e-atribui-coronavirus-a-satanas/>. Acesso em: 16 jun. 2020. 
no contexto das teopatias, o mal sofrido por Deus é sobretudo a iniquidade. Se Deus simplesmente é derrotado pela iniquidade, ele não estaria corroborando sua força destrutiva? Nesse caso, é preciso pensar o que estamos a chamar de teorevolta. Segundo a nossa hipótese, somente ela permite conjugar sofrimento humano, sofrimento divino e revolta, tanto divina quanto humana. No tempo do novo coronavírus, em que populações são alvo de práticas necropolíticas, a iniquidade dá as caras. É preciso levar em conta que, diante da lógica da iniquidade, a teorevolta não é solução, mas resistência. Para dar conta dessa questão, por meio de uma abordagem cartográfica, ou seja, do mapeamento de discursos históricos, dividiremos o presente artigo em três momentos, a saber: 1. Teodiceia como indiferença ontológica de Deus; 2. Das teopatias aos limites de um Deus sofredor; 3 . Do sofrimento às revoltas de Deus: contra a lógica da iniquidade. Terminaremos com algumas considerações finais, que devem integrar o caminho percorrido e a pandemia da Covid-19.

\section{Teodiceia como indiferença ontológica de Deus}

Ao considerar os níveis discursivos acerca do mal na obra $O$ mal, Ricoeur consagra à teodiceia um lugar de destaque, o que fica evidente na quantidade de páginas dedicadas a ela, se comparadas aos demais níveis/estágios de abordagem do mal (mito, sabedoria, gnose e dialética "quebrada"). Chamam atenção as condições de possibilidade do reconhecimento da teodiceia por ele elencadas.

Só se tem o direito de falar em teodiceia quando: a) o enunciado do problema do mal repousa sob proposições que visam à univocidade; é o caso das três asserções geralmente consideradas: Deus é todo-poderoso; sua bondade é infinita; o mal existe; b) o fim da argumentação é claramente apologética: Deus não é responsável pelo mal; c) os meios empregados devem satisfazer à lógica da não-contradição e da totalização sistemática. ${ }^{5}$

Em suma, só há teodiceia quando um discurso tematiza o mal à luz de proposições unívocas que entendem Deus como ente metafisicamente supremo, visando a uma defesa de Deus na produção do mal e se orientando racionalmente pelo princípio lógico (também ontológico) da não contradição e pela busca de enquadramento sistemático do mal. Somente assim a teodiceia garante inteligibilidade ao mal. O mais importante, contudo, vem em seguida: somente a metafísica ocidental e a ontologia dela dependente possibilitaram o surgimento histórico da teodiceia. Por um lado, a metafísica perguntou pelos caracteres gerais dos entes (substância, acidente etc.). Por outro, ela questionou o mais ente dos entes como fonte de significação da totalidade e como índice de concretização de alguns caracteres encontrados nos entes em geral. Esse ente, obviamente, é Deus. Esse caráter dual da metafísica e o acento proposital no conceito de Deus entendido como entidade suprema foi compreendido por Heidegger

5 RICOUER, Paul. O mal: um desafio à filosofia e à teologia. Campinas: Papirus, 1988. p. 35. 
como o caráter onto-teológico da metafisica ${ }^{6}$, ao mesmo tempo em que fora apropriado por Ricoeur para interpretar a condição de possibilidade hermenêutica da teodiceia. Como Ricoeur afirma: "A teodiceia, no sentido restrito, é o florão da onto-teologia". Apesar de aqui não ser o lugar propício para um aprofundamento especulativo da noção de onto-teologia, é preciso levar em consideração que essa condiciona as três características anteriormente destacadas da teodiceia segundo a abordagem de Ricoeur.

Das considerações anteriores, o que aqui nos interessa é a identificação de Deus com a noção metafísica de absoluto, o que subjaz à ideia de onipotência divina, noção conjugada com outros conceitos também metafísicos, como imutabilidade, ato puro, perfeição suprema etc., conceitos necessários para se entender o mal como uma falha ontológica, possibilitado pela condição ontológica dos entes finitos e impossível de ser encontrada no ser supremo, uma vez que seus atributos ontológicos, de um modo ou de outro, deixam clara a independência ontológica de Deus - daí seu caráter absoluto ou ontologicamente "solto", independente. Nesse caso, a teodiceia não se atém somente à apologética; não somente isenta Deus da responsabilidade pelo mal. A teodiceia exige que o ser de Deus, de algum modo, seja incapaz de ser atuado pelo mal. Em outras palavras, o mal não atravessa o coração de Deus. Nesse sentido, a defesa de Deus diante do mal é a salvaguarda de sua indiferença ontológica em relação a ele. Recorreremos aqui a Santo Agostinho, talvez o mais célebre autor do que estamos a chamar de teodiceia clássica. O recorte a ser feito em suas obras é orientado pelos próximos tópicos, que dependem diretamente de uma compreensão mínima da apatia divina tal qual pensada pela teodiceia. ${ }^{8}$

Que se leve inicialmente em consideração a questão: qual pergunta sustenta os discursos das teodiceias? Levando em conta Santo Agostinho, é possível dizer que a pergunta central das teodiceias é: “o que é o mal?" Trata-se de uma questão de matriz claramente filosófica: perguntar pelo "quê" de algo é inquirir sua natureza ou propriedades essenciais. Ora, exatamente essa questão é ressignificada por Agostinho, ao questionar o que é o mal. Isso porque a realidade do mal, antes de ser uma quimera, é um fato relativo, uma vez que não pode ser compreendido como ontologicamente autossubsistente. $\mathrm{O}$ mal existe, mas não há uma natureza que possa, por si mesma, ser considerada má. Daí a primeira conclusão: a natureza do mal implica o fato de o mal não ser natureza. Por isso, antes de sabermos como se define o mal, é necessário compreender previamente onde ele se instaura, a saber, o bem. Por outro lado, não é possível entender o bem de um ser relativo (criatura) onde incide o mal, se não considerarmos a noção de bem supremo, princípio metafísico-ontológico de onde derivam os entes finitos em meio aos quais o mal atua. Se levarmos em conta o fato de a obra A natureza do bem (De natura boni) ser um marco na capacidade de conceptualização agostiniana no que concerne à questão do mal, ainda que diversos temas acerca desse problema não tenham sido colocados nesse escrito antimaniqueísta de juventude

6 HEIDEGGER, Martin. Identidade e diferença. São Paulo: Abril Cultural, 1973. (Coleção Os Pensadores). 7 RICOUER, 1988, p. 35.

8 ALMEIDA, Edson Fernando de. Do viver apático ao viver simpático: sofrimento e morte. São Paulo: Loyola, 2006. 
(graça, pecado original, relação entre livre-arbítrio e liberdade), chama atenção o fato de que seu título menciona o bem e não o mal. Trata-se de uma marca importante da questão do mal: só é possível abordá-lo por meio da pré-compreensão da natureza do bem, suporte ontológico do mal. Que se leve, nesse momento, em consideração o primeiro capítulo desse livro:

Deus é o Bem Supremo, acima do qual não há outro: é o bem imutável e, portanto, verdadeiramente eterno e verdadeiramente imortal. Todos os outros bens provêm d'Ele, mas não são da mesma natureza que Ele. O que é da mesma natureza que Ele não pode ser senão Ele mesmo. Todas as outras coisas, que foram feitas por Ele, não são o que Ele é. E, uma vez que só Ele é imutável, tudo o que Ele fez, e que foi feito do nada, está sujeito à mudança. Ele é tão onipotente, que do nada, ou seja, do que não tem ser, pode criar os maiores e os menores bens, celestiais, espirituais e corpóreos. [...]

Por outro lado, toda e qualquer natureza enquanto natureza é sempre um bem - não pode provir senão do supremo e verdadeiro Deus, porque o ser de todos os bens, tanto os que pela sua excelência se aproximam do Sumo Bem como os que pela sua simplicidade se afastam d'Ele, não pode provir senão do Sumo Bem. Por conseguinte, todo e qualquer espírito está sujeito à mudança, e todo e qualquer corpo provém de Deus - e a espírito e matéria reduz-se toda natureza criada. ${ }^{9}$

Que se destaquem alguns pontos relevantes dessa citação. Em primeiro lugar, Agostinho assinala como primeiro atributo de Deus a noção de sumo bem. Para deixar claro por que o bem divino é supremo, Agostinho o conjuga com o atributo da imutabilidade. Ser o sumo bem é não se modificar e, por conseguinte, não perecer, ou seja, ser imortal. Ora, sem devir, o ser divino não pode ser considerado temporal. Logo, é preciso afirmar que Deus é eterno, ou melhor, a eternidade é Deus. Agostinho não para aí. Ele acrescenta a ideia segundo a qual Deus é criador e, assim, implica todos os seres em sua análise dos atributos divinos. Não geradas, uma vez que a geração é o modo como as pessoas trinitárias derivam umas das outras (o Filho é gerado pelo Pai e o Espírito Santo, segundo o cristianismo latino, procede do Pai e do Filho), as criaturas devem ser consideradas bens. Nesse caso, o bem não pode receber de modo idêntico os mesmos atributos divinos. Daí a mutabilidade da criação. Tudo que não é Deus provém de Deus, mas não recebe do mesmo modo os atributos de Deus em seu ser. Se toda criatura é um bem, é possível dizer que se trata, então, de um bem relativo. Nesse caso, o devir atravessa e condiciona o bem criatural. A natureza relativa da criatura traz consigo a presença do devir e a impossibilidade de ser imutável, imortal e eterna.

Os bens relativos possuem intensidades distintas, isto é, há criaturas que assinalam bens maiores que outras. $\mathrm{O}$ critério para a hermenêutica intensiva dos seres criaturais se identifica com o conjunto de seus atributos, todos eles caracterizando a noção agostiniana de bem. Sem detalhar o conteúdo desses atributos, fazemos uma rápida menção aos três atributos ontológicos que se identificam com o bem: modo, espécie e ordem.

9 AGOSTINHO, Santo. A natureza do bem. Rio de Janeiro: Sétimo Selo, 2006. cap. I. 
Assim, estas três coisas: o modo, a espécie e a ordem - para não falar de outros incontáveis bens que a estes se reduzem -, estas três coisas, repito: o modo, a espécie e a ordem, são três bens gerais que se encontram em todas as coisas criadas por Deus, tanto as espirituais como as corporais. ${ }^{10}$

Se toda criatura possui, de alguma forma e em alguma medida, modo, espécie e ordem, só cabe concluir: "toda e qualquer natureza é boa"11. Ora, ao dizer que toda natureza é boa, Agostinho intenta, primeiramente, identificar ontologicamente ser e bem ou natureza e bem. Em um segundo momento, seu propósito é deixar claro que o mal não é uma natureza, não é uma criatura. Por isso o mal não é um ente. Em terceiro lugar, Agostinho intenta inserir a noção platônica de participação na relação entre o bem supremo e os bens relativos. Todo bem criatural participa com graus distintos do bem supremo (Deus). Como, então, entender o mal a partir desse arcabouço ontológico-metafísico?

Se a natureza da criatura não pode ser má, o mal só pode ser uma certa deformação da própria criatura, algo que acontece com ela e atua no bem relativo que ela mesma é. O bem relativo, suscetível ao devir, pode vir a ser em dissonância com sua natureza, sofrendo, assim, algum tipo de corrupção, seja no modo de atuação, seja ainda na deformação da integralidade de sua configuração originária, como acontece em alguns animais, quando são mutilados. Por isso, afirmou Agostinho: “o mal não é senão a corrupção ou do modo, ou da espécie, ou da ordem naturais. A natureza má é, portanto, a que está corrompida, porque a que não está corrompida é boa"12. Um ente corrupto (corruptus) é um ser privado da integralidade de sua natureza. Daí a expressão agostiniana privatio boni, privação do bem, utilizada em diversos (con)textos para definir o mal. ${ }^{13}$ A partir da resposta à questão “o que é o mal?", Agostinho está pronto para saber de onde ele procede (unde malum?). O mal não é uma quididade, mas atua na quididade boa de uma criatura determinada. Mas qual a condição de possibilidade da corrupção? Agostinho afirma que é a natureza da criatura, uma vez que ser criado significa advir do nada (ex nihilo). Não sendo gerada do ser de Deus, a criatura vem do nada e leva consigo a marca do nada. Por isso a criação é ontologicamente mutável. Ser criado é ser ontologicamente mesclado: possuir a mescla de ser e de nada em graus distintos, segundo a natureza de cada criatura.

A condição ontológica da criatura e a especificidade de sua natureza possibilitam experiências diversas do mal. Ainda que involuntariamente, toda criatura possui alguma relação com o mal, porquanto seu devir a faz experimentar a corrupção da integralidade de sua natureza. Ora, nesse caso, a fonte do mal está na finitude da

10 AGOSTINHO, 2006, cap. III.

11 AGOSTINHO, 2006, cap. III.

12 AGOSTINHO, 2006, cap. IV.

13 É por esse motivo que Santo Tomás de Aquino afirmou: "Digo, por conseguinte, que o mal não é algo, embora aquilo a que sucede ser mau seja algo, uma vez que o mal não priva senão de um bem particular; assim como ser cego não é algo, ao passo que aquele a que sucede o ser cego é algo" (AQUINO, Santo Tomás de. Sobre o mal. Rio de Janeiro: Sétimo Selo, 2005. q. 1, art. 1, resp.). 
condição criatural. Contudo, esse mal possui um sentido de ordem estética. Visto pela perspectiva da totalidade organizada (ordenada) da criação, o mal dos seres criados, em verdade, se identifica com o mal das partes de um todo. Quando as partes perecem, o todo é rearticulado, pois novos seres ocupam os espaços antigos ou ainda novos seres contribuem para a produção de uma nova unidade criatural. Porquanto a harmonia de um todo assinala beleza, o mal das partes da criação concorre para uma nova irrupção da beleza. Esse mal, que se poderia caracterizar como mal natural, possui, para Agostinho, um horizonte de significação estético. Nas suas palavras: "As coisas temporais aparecem e desaparecem para dar lugar a outras, e em seu gênero isso é belo; e as coisas que perecem ou deixam de ser não turvam nem perturbam o modo, a espécie e a ordem do conjunto das criaturas" ${ }^{14}$. Entretanto, há uma corrupção que não provém do perecimento "natural" da criação, posto que produzido por uma criatura específica, que possui metafisicamente a possibilidade de introdução da corrupção no mundo, a saber, o ser humano.

Para Agostinho, assim como para toda "teodiceia clássica", a preocupação central da tematização do mal está centrada no ser humano. Basta levar em conta a obra O livre-arbitrio, na qual a questão do mal imediatamente aparece articulada com o ser humano. Após ser questionado por Evódio se Deus é o autor do mal, Agostinho diz: "se sabes ou acreditas que Deus é bom - e não nos é permitido pensar de outro modo -, Deus deve distribuir recompensas aos bons, assim como castigos aos maus"15. Ora, os males que podem ser castigados se referem àqueles produzidos pelo ser humano, pois os demais seres da criação, com exceção dos anjos, não podem ser considerados culpados pelos males praticados ou sofridos. Como afirma Agostinho:

Cada pessoa ao cometê-lo é o autor de sua má ação. Se duvidas, reflete no que já dissemos acima: as más ações são punidas pela justiça de Deus. Ora, elas não seriam punidas com justiça, se não tivessem sido praticadas de modo voluntário ${ }^{16}$.

Em última instância, é a liberdade da vontade (livre-arbítrio) a fonte dos males instituídos pelo ser humano no mundo. Nesse caso, o ser humano se relaciona com dois males: o pecado voluntariamente cometido e o castigo sofrido por causa dos pecados cometidos, chamado mal de pena (poena) ${ }^{17}$ A pena introduzida no mundo objetiva reinserir o pecador na ordem instituída por Deus. ${ }^{18}$ Deus, portanto, não quer o mal, nem é autor de qualquer corrupção. O mal moral é problema humano, fruto de sua racionalidade e da liberdade de sua vontade.

As informações acima já deixam aparecer paradigmaticamente os elementos centrais da teodiceia classicamente pensada. Deus é imutável e onipotente; Deus é bem supremo (absoluto); Deus é criador; Deus não pode ser autor do mal; o mal não

\footnotetext{
14 AGOSTINHO, 2006, cap. VIII.

15 AGOSTINHO, Santo. O livre-arbitrio. São Paulo: Paulus, 1995. Introdução, 1, 1.

16 AGOSTINHO, 1995, introdução, 1, 1.

17 AGOSTINHO, 2006, cap. VII.

18 AGOSTINHO, 2006, cap. IX.
} 
é uma natureza, mas a privação da integralidade de uma natureza finita; logo, o mal procede da condição finita da criação, seja por causa do elemento corrosivo do devir, seja ainda devido à má atuação do livre-arbítrio e aos castigos divinos que objetivam reintroduzir a ordem na desordem nascida do pecado. Ainda que a graça divina possibilite ao livre-arbítrio querer e realizar o bem, isso não implica qualquer transformação ontológica do ser divino. Em outros termos, o mal não incide em Deus, pois seu ser continua tal qual sempre foi e será, a despeito da força destrutiva do mal. Por esse motivo é possível afirmar que o sentido da divindade defendida pela teodiceia é o da imunidade ontológica. Nesse caso, ser imune é ser impassível ao poder corrosivo do mal. Daí a conclusão: a indiferença ontológica de Deus é um dos pressupostos hermenêuticos da teodiceia.

\section{A noção de teopatia: só um Deus que sofre pode nos ajudar}

É precisamente tal indiferença ontológica que receberá uma profunda crítica da teologia, sobretudo depois de Auschwitz. Filósofos e teólogos judeus como Hans Jonas, Richard Rubenstein, Abraham Heschel, bem como teólogos e teólogas cristãos como Johann Baptist Metz, Dorotheee Sölle, Jürgen Moltmann, por exemplo, tentarão reformular a questão de Deus sobretudo a partir da Shoá, perguntando-se se é possível falar de Deus a partir desse inominável genocídio. Voltam-se à questão da teodiceia e destroem a noção de impassibilidade divina. Trata-se da morte do onipotente Deus bom criador. E nasce desses estertores o que podemos chamar de teopatia, a ideia de um Deus capaz de sofrer e morrer com e nas criaturas pelo seu amor. Ao mesmo tempo, surge a questão da antropodiceia, ou seja, como as boas criaturas de Deus puderam perpetrar tais crimes? ${ }^{19}$ Nenhuma teologia contemporânea, que tenha enfrentado as dores do holocausto, pôde tratar do mesmo jeito a questão da teodiceia. Para autores como Metz, se há alguma contemporaneidade no tema da teodiceia, ela diz respeito não à sua retomada com vistas à justificação de Deus diante do mal, mas da retomada da pergunta de como se pode falar de Deus ante a inescrutável história de sofrimento do mundo. ${ }^{20}$ Para esse autor, essa pergunta jamais pode ser eliminada e muito menos respondida de forma conclusiva. Trata-se da pergunta escatológica por excelência, para a qual a teologia não deve procurar tanto uma resposta reconciliadora, mas uma nova linguagem que impeça que tal questão seja esquecida. Pois quem formula o discurso sobre o Deus de Abraão, Isaque e Jacó sem incluir o iniludível lamento de Jó, faz qualquer coisa, menos teologia.

No campo judaico, destaca-se a figura de Hans Jonas e sua teopatia. Para o filósofo judeu, o ser de Deus é afetado por seu processo criador, ou seja, Deus sofre o devir criatural e ao mesmo tempo sofre o devir no seu próprio ser. Transformado num

19 KUSCHEL, Karl-Joseph. Teodiceia e antropodiceia: o mal na teologia depois de Auschwitz. IHU ONLINE, edição 438, março de 2014. Disponível em: <http://www.ihuonline.unisinos.br/artigo/5400-karl-josefkuschel-4>.

${ }^{20}$ METZ, Johann Baptist. Memoria passionis: una evocación provocadora en una sociedad pluralista. Santander: Sal e Terra, 2007. 
ente, Deus deixa-se afetar pelos acontecimentos do mundo, não como quem interfere nele, mas como alguém que está sujeito a ele. Jonas chega a construir uma narrativa mitopoética que ressalta a fragilidade de Deus, sua impossibilidade de interferência no devir da criação. E é precisamente tal fragilidade que possibilita ao ser humano ser um parceiro para redimir o mundo com seu criador e ao mesmo tempo redimir o próprio criador no sofrimento do mundo. ${ }^{21} \mathrm{Na}$ mesma esteira, Zizek afirmou que a verdade traumática do acontecimento da Shoá resiste a uma integração no universo de quaisquer significados ${ }^{22}$, como presente no texto Apenas um Deus que sofre pode nos salvar. Recorrendo ao teólogo Dietrich Bonhoeffer, lembrará que só o Deus que sofre pode nos ajudar, pois o sofrimento inominável de seis milhões de judeus é também a voz do sofrimento de Deus e o próprio excesso desse sofrimento em relação a qualquer medida humana o torna divino. Em outros termos: "O fiasco de Deus ainda é o fiasco de Deus"23.

Foi o teólogo alemão Jürgen Moltmann quem tematizou de maneira mais contundente o estatuto da teopatia a partir da morte do Deus da onipotência teodiceica. O tema é recorrente em sua obra, mas no capítulo II da obra Trindade e Reino de Deus $^{24}$, que tem como título “A paixão de Deus”, Moltmann traça um panorama mais sistemático do que seja tal noção. Para ele, a substância divina tem sido interpretada pela tradição como sendo imune à diversidade, à diferença e pluralidade. Trata-se, portanto, de uma substância autossuficiente totalmente oposta ao mundo móvel dos sofrimentos humanos. Nada há nela que tenha a ver com a transitoriedade do mundo. Tal impassibilidade, entretanto, não se sustenta quando adentramos a tradição bíblica, sobretudo em seu núcleo central, os evangelhos. Ali encontramos as narrativas do sofrimento de Cristo. E se se crê no sofrimento de Jesus como sofrimento do Filho de Deus, depara-se então com um Deus que está envolvido com as tramas do devir mundano. Ocorre que a tradição cristã formulou suas narrativas crísticas incorporando os relatos da paixão à noção de impassibilidade divina. Portanto a tradição justapôs o axioma grego da impassibilidade da divindade suprassensível ao tema do sofrimento de Cristo. Ora, quanto mais se acentua a impassibilidade divina, tanto mais débil será a identificação de Deus com a paixão de Cristo e, portanto, mais débil será a descoberta de Deus nessa mesma paixão, ou seja, conciliar analógica e cristologicamente apatia e paixão, esse tem sido o trabalho da teologia cristã desde a igreja antiga.

Moltmann se vê às voltas com a ideia de pathos divino de Abraham Heschel, para dar conta da questão da teopatia. É que Heschel recorre ao profetismo bíblico para desenvolver sua noção de pathos de Deus. O que os profetas tinham não eram ideias sobre Deus, mas uma experiência de Deus. Deus é em si mesmo livre, mas, por

${ }^{21}$ CABRAL, Alexandre Marques. Hans Jonas, gnosticismo e a questão de Deus: entre redenção da natureza e compromisso ético. 2015.

${ }^{22}$ ZIZEK, Slavoj; GUNJEVIC, Boris. O sofrimento de Deus: inversões do Apocalipse. Belo Horizonte: Autêntica, 2015.

${ }^{23}$ ZIZEK; GUNJEVIC, 2015, p. 133.

${ }^{24}$ MOLTMANN, Jürgen. Trindade e Reino de Deus: uma contribuição para a teologia. Petrópolis: Vozes, 2000. p. 35-74. 
meio do seu pathos, revela-se ao povo da sua aliança. E à experiência desse pathos corresponde a simpatia profética, resposta humana ao pathos de Deus. ${ }^{25}$ Moltmann vê o movimento pático hescheliano exemplificado na noção rabínica e também cabalística da shekinah. Trata-se das auto-humilhações divinas pelas quais se dá uma acomodação da presença de Deus em meio às fraquezas humanas. São adaptações do amor, são coabitações da glória divina às perseguições sofridas por Israel, aos seus exílios, à dor de seus mártires. Moltmann evoca a figura de Franz Rosenzweig que afirmou que somente na redenção, quando todas as coisas voltarem ao seu lugar, quando todas as opressões forem desfeitas, Deus será único e único será o seu nome. O exílio da shekinah só conhecerá seu ocaso no duplo movimento da oração e da ação humana. Na oração, mediante a profissão de fé na unidade de Deus traz-se a glória de Deus para junto de si. Mas tal exílio se desfaz também quando a alienação é superada pela ação do bem visando à instauração da harmonia divina num mundo unificado. Nesse movimento reside o sentido da palavra tikkun. Tal compreensão pática admite uma ruptura em Deus, na medida em que esse experimenta uma ruptura em si ao envolver-se com o mundo. E por que ocorre tal ruptura? Por causa do pathos pelo qual Deus se auto-humilha para estar próximo de seus parceiros. Que baste esse exemplo de uma teologia que teria conseguido romper com as amarras de um Deus apático, segundo a abordagem moltmanniana.

Uma terceira escola teológica que ousou questionar a ideia da impassibilidade divina é aquela representada por Miguel de Unamuno e seu texto Do sentimento trágico da vida. Tal sentimento é expressão de uma contradição fundamental: a vida é uma tragédia, uma batalha constante sem vitória e sem esperança de vitória. Angústia é a palavra que Unamuno encontra para falar desse sentimento. Tal angústia é a expressão da imagem que Unamuno tem de Cristo, em sua agonia na cruz. A partir do sentimento trágico da vida e da visão do Crucificado, Unamuno desenvolve sua teologia como teologia da aflição divina, no escopo da quebra da impassibilidade divina.

Foi esse escândalo do cristianismo entre judeus e helenos, entre fariseus e estoicos, e esse que foi seu escândalo de um Deus que se fez homem para padecer, morrer, e ressuscitar e por ter padecido e morrido, de um Deus que sofre e morre. Essa verdade de que Deus padece, diante da qual sentem-se aterrados os homens, é a revelação das próprias entranhas do Universo e de seu mistério, que nos revelou ao enviar seu Filho para que nos redimisse, sofrendo e morrendo. Foi a revelação do divino da dor, pois só é divino o que sofre. [...] Quem não sofre e não sofre porque não vive, é esse lógico e congelado ens realissimum, é o primum movens, é essa entidade impassível e, por ser impassível, não mais que pura ideia. ${ }^{26}$

Ou seja, o Deus vivo é um Deus que ama e o Deus que ama é aquele que se revela amorosamente no seu sofrimento. Portanto Deus é limitado pelo mundo em que vive e do qual procura libertar-se a si e a nós. Assim é que Deus e o mundo criado

${ }^{25}$ HESCHEL, Abtaham J. The Prophets. New York: Harper Collins, 2001.
${ }^{26}$ UNAMUNO, Miguel. Do sentimento trágico da vida. São Paulo: Martins Fontes, 1996. p. 195-196.

Estudos Teológicos | São Leopoldo | v. 60 | n. 2 | p. 446-465 | maio/ago. 2020 
encontram-se em um processo de libertação. Deus participa das dores humanas e nós participamos das dores divinas. Não somos nós apenas que necessitamos da compaixão divina, também Deus precisa da compaixão humana. "Crer em Deus é amá-Lo, e amá-Lo é senti-lo sofrendo, compadecendo-se Dele. [...] A angústia religiosa não é senão o divino sofrimento, sentir que Deus sofre em mim e que eu sofro Nele., ${ }^{27}$

Outra vertente teológica capaz de questionar a ideia da impassibilidade divina é a representada por Berdiaev. Para este, o mundo, sua existência e história são filhos da liberdade. Deus desejou a liberdade; não fosse isso, o processo do mundo não teria ocorrido. A história humana é uma tragédia, mas não uma tragédia do amor como para Unamuno, a tragédia do mundo de Berdiaev é a tragédia da liberdade. A liberdade humana é a expressão da paixão divina, é a forma como o amor se configura. Por isso o sofrimento de Deus está no centro dessa aventura, porque ele deseja a liberdade. Ou seja, trata-se da tragédia de um Deus que deseja a liberdade e só pode conservá-la mediante o sofrimento do seu amor. Portanto, se o mistério da liberdade reside no próprio Deus, então há uma tragédia em Deus mesmo, uma espécie de "natureza obscura" no seu interior, no dizer de Jakob Böhme.

Se na vida divina se desenvolve uma tragédia da paixão, uma certa fatalidade divina, em cujo centro se encontra o sofrimento de Deus, do Filho de Deus, e se nesse sofrimento se realiza a salvação do mundo, a libertação do mundo, isso só pode ser explicado admitindo-se o fato de que existe no próprio seio da vida divina um princípio profundo, como um conflito trágico, ou um movimento trágico, ou uma paixão trágica. ${ }^{28}$

A luta de Berdiaev é contra o que chama de monismo. Esse que pensa a divina presença como estando acima dos conflitos e processos, acima das coisas móveis do mundo aparente. Por esse esquema, a divindade mantém-se em oposição ao múltiplo, sendo o imutável em oposição ao móvel, o idêntico a si mesmo em oposição a todas as coisas que com ele não se identificam. Porque nega o movimento na natureza divina, o monismo nega também a própria vida trinitária, pois que no âmago da vida divina revela-se uma íntima sede de paixão da divindade, a saudade de um outro pelo qual anela Deus, isto é, um outro de si mesmo, o homem feito à sua imagem e semelhança. Tal anelo se dá não por carência do ser, mas precisamente pela suberabundância da sua plenitude criadora nessa lacuna da vida do absoluto. Portanto, nessas quatro concepções teológicas, é o sofrer divino no sofrer humano que levanta a pergunta por Deus.

Essas compreensões teológicas apontam para a necessidade de uma revolução no conceito de Deus. Para Moltmann ${ }^{29}$, nossa história de sofrimento está suprassumida em Deus. A morte está em Deus. Ele sofre por nós, conosco. A rejeição está no interior do próprio Deus. Pensando nos momentos da tradição em que a rocha da impassibilidade divina foi trincada, a fragilidade de Deus, sua impermanência, sua presença no fluxo do devir e mesmo sua necessidade de que suas criaturas o socor-

\footnotetext{
27 UNAMUNO, 1996, p. 199.

28 BERDIAEV apud MOLTMANN, 2010, p. 57.

29 MOLTMANN, Jürgen. Paixão pela vida. São Paulo: Aste, 1978. p. 64.
} 
ram, recoloca a questão da teodiceia, autenticando a passagem de uma justificativa do silêncio divino diante do sofrimento inocente, para uma frágil presença divina no sofrer humano, sobretudo o sofrimento sem sentido. Como pode, pergunta-se a teóloga alemã Dorothee Sölle, manifestar-se a esperança em face do sofrimento humano? A resposta é a história de Eli Wiesel, um sobrevivente de Auschwitz:

As SS enforcam dois judeus adultos e um jovem na presença do pessoal do campo reunido. Os homens tiveram morte rápida, mas a agonia do jovem durou meia hora. “Onde está Deus? Onde está ele?” pergunta alguém atrás de mim. Quando, decorrido prolongado tempo, o jovem continuava a sofrer, pendurado na corda, tornei a ouvir o homem gritando: "Onde está Deus nesta hora?" E ouvi uma voz responder dentro de mim: "Onde está ele?... Ali está ele, no patíbulo" 30.

Sölle recorre à resposta inferida do ensino cabalístico sobre a mencionada shekinah. A glória divina desce pessoalmente ao mundo e faz habitação nas criaturas sofredoras e suas máculas. Em sua shekinah, Deus está presente no patíbulo em Auschwitz. Na perspectiva exegética cristã, para Sölle, a história mítica de Cristo aparece de forma fragmentada na acima transcrita história de Auschwitz, espelhada em três vozes diferentes. O grito de Jesus na cruz, "Deus meu, por que me desamparaste?", aparece na voz do homem atrás do narrador; o jovem morre como Jesus morreu e o narrador ouve uma voz e lhe diz onde Deus se encontra: precisamente no enforcado. Entretanto, enquanto em Jesus aparece ao mesmo tempo a interrogação, a vítima e a resposta, na história do jovem esfacela-se toda a comunicação: o interrogante não recebe a resposta, a mensagem não alcança o mortituro e o narrador fica a sós com sua voz. Dois são, para Sölle, os significados da afirmação de que Deus ali está no patíbulo. Em primeiro lugar, trata-se de uma afirmação sobre Deus. Ele não é o carrasco nem o espectador onipotente, muito menos o todo-poderoso tirânico. Seja o que for que o significante Deus signifique nesse contexto, ele está entre as vítimas, ele está enforcado. Deus está pendurado no patíbulo. Em segundo lugar, há uma afirmação sobre o jovem e vale aqui a confissão reveladora do capitão romano na cena de Jesus na cruz: "Na verdade este é o filho de Deus". Não há lugar para cinismos como a afirmação tradicional de que "ele está no céu pela ressurreição, junto a Deus". Esse jovem e todos os seis milhões de judeus mortos são o filho amado de Deus. "Nenhum céu é capaz de reparar o que aconteceu em Auschwitz. Mas o Deus que não é um Faraó maior prestou cabal explicação ao sucedido? Sofrendo junto, morreu junto na cruz." 31 Prossegue Sölle: "Deus não possui outras mãos senão as nossas". E fazendo clara crítica a certas teologias da esperança, dirá: “Também 'o futuro', que hoje frequentemente é relacionado à palavra mítica 'céu', de modo algum consegue impedir que o jovem deva morrer em Auschwitz. Se há algum sentido para a palavra futuro em contexto é apenas de que ele, o futuro, poderá conservar a memória dessas pessoas e mediante tal memória, poder-se-á combater melhor o bom combate contra a morte.

30 SÖLLE, Dorothee. Sofrimento. Petrópolis: Vozes, 2007. p. 151.

31 SÖLEE, 2007, p. 154. 
Conclui-se, com tudo o que vimos afirmando, que a rocha do sofrimento fez ruir o teísmo de um Deus todo-poderoso e bom. Mas, a essa altura, nos perguntamos: não será também a ideia de um Deus que sofre, de um Deus fraco, de um Deus incapaz de fazer frente ao fluxo do devir com o qual está identificado, uma nova forma justificativa do silêncio de Deus? Metz chega a propor uma objeção ao discurso sobre o Deus que sofre, considerando tal discurso uma via adequada da teologia contemporânea para esquivar-se do dado escatológico ao oferecer de alguma forma uma resposta tranquilizadora, já que a linguagem do sofrimento de Deus acaba poupando Deus da pergunta inquietante: por que, Deus? ${ }^{32}$. A suspeita de Metz é que não é por acaso que a teologia insiste em falar do Deus que sofre e assume nosso sofrimento numa época que oferece à estetização um papel-chave em nossa cultura intelectual. Dito na forma de uma pergunta, o discurso do Deus que sofre e morre não sofre uma certa estetização pós-moderna do tema do sofrimento ${ }^{33}$ Ou seja, se Deus sofre, então o sofrimento deixa de ser uma objeção contra ele. Nesse sentido, como situar o clamor das tradições bíblicas, os Salmos imprecatórios, o suspiro oprimido de um homem como Jó? Como encarar o desespero de Jesus na cruz: Deus meu, Deus meu, por que me desamparaste?

\section{Do sofrimento às revoltas de Deus: contra a lógica da iniquidade}

O enfraquecimento ontológico de Deus transformou-se em horizonte hermenêutico alternativo à teodiceia. Como estratégia principal, como vimos, a teologia contemporânea judaico-cristã inscreveu o sofrimento na vida divina. É Deus mesmo quem sofre no sofrimento e nos males sofridos pela pessoa sofredora, sobretudo aqueles males nascidos da injustiça. Trata-se, portanto, da gênese da teopatia, conquista importante da teologia atual. Contudo, se atentarmos para um gesto pertencente à teopatia e de certa forma destacado por Metz, então, em verdade, parece que a alternativa proposta por essa "nova" compreensão do mal e do sentido do sofrimento assinala somente uma inversão da teodiceia e não sua superação ou mesmo desconstrução. Isso porque tudo parece corroborar a hipótese segundo a qual a teologia do sofrimento de Deus, por um lado, absolve novamente Deus do "crime" da autoria do mal no mundo; e, em segundo lugar, o "tribunal da razão teológica" transforma o "Deus réu” em "Deus vítima", o que preserva o caráter judicializante da razão teológica tradicionalmente presente nas teodiceias. Deve-se ainda acrescentar que a inversão da onipotência divina metafisicamente pensada não é, em sentido próprio, uma superação, uma vez que as notas conceituais da noção de onipotência continuam vigentes sob o modo da negação.

Dizer que nos campos de concentração nazistas Deus estava crucificado com cada pessoa assassinada é somente um aspecto da questão da teopatia. Se essa for a melhor resposta possível para o problema do mal no mundo, então, ela pode ser en-

\footnotetext{
32 METZ, 2015, p. 31.
}

33 METZ, 2015, p. 32. 
tendida como legitimadora da tese do bode expiatório, tal qual pensada por Girard. ${ }^{34}$ Sem entrar nos pormenores dessa tese, é digno de nota que a produção de vítimas sacrificais atende ao interesse primário de amenização dos conflitos generalizados que atravessam uma sociedade e que precisa, vez por outra, de um objeto comum para canalizar o ódio comunitário, "objeto" esse que tenha por função aplacar temporariamente a violência estrutural da cultura e harmonizar grupos de pessoas consideradas dignas de ser preservadas. A escolha da vítima tem como critério o fato de sua morte não causar revolta nas demais camadas populares, ou seja, sua morte não potencializa o caos. Em outros termos, vidas sacrificáveis são aquelas que, uma vez imoladas, não produzem revolta social. Daí sua ambiguidade: por um lado, vítimas sacrificáveis são canalizadoras do ódio, por outro, fomentam reverência, uma vez que promovem reordenação da sociedade. ${ }^{35}$ Ora, poder-se-ia perguntar: não é possível e plausível entender as mortes nos campos de concentração nazistas como veículos de reordenação social? Não seriam esses campos estratégias de regulação social que utilizariam um mecanismo de matriz religiosa, que é o caso do sacrifício da vítima, conforme o entendimento de Girard? Nesse caso, a teopatia seria somente um momento necessário da lógica do sagrado, que exige a vítima, exige o assassinato como forma de organização social. Em outros termos, o Cristo que morre no campo de concentração nada teria a oferecer de alternativo à lógica que promove continuamente formas genocidas de estruturação da cultura. Por isso é preciso admitir que o fato de Deus ser atravessado pelo sofrimento nascido da injustiça não é capaz de responder suficientemente ao problema do mal. Por esse motivo, ousamos aventar a hipótese segundo a qual é preciso repensar a teopatia (jamais descartável) por meio de uma teorevolta. Com isso queremos afirmar que a noção de revolta possibilita inscrever a relação entre Deus e mal em um horizonte efetivamente alternativo, irredutível à teodiceia. Um pequeno ensaio da plausibilidade dessa hipótese será realizado neste tópico.

Levaremos em conta um topos do pensamento de Rubem Alves, que talvez nos forneça um pista hermenêutica para o problema que caracterizamos. Em Por uma teologia da libertação, Alves articula dois conceitos para pensá-los de modo crítico, a saber, liberdade e esperança. Partindo do princípio de que o ser humano é, simultaneamente, ser no mundo e ser com o mundo, Alves assinala que todo ser humano é um ser de resposta às interpelações históricas do mundo. Aliás, o mundo só pode ser histórico porque as respostas humanas às suas interpelações produzem devir no mundo. Como ele afirma: "O homem responde porque descobre o seu mundo como se fosse uma mensagem a ele endereçada, como um horizonte em direção ao qual pode se projetar. E, ao responder, o mundo torna-se diferente: torna-se histórico" ${ }^{36}$. A recíproca é verdadeira: toda resposta humana às interpelações mundanas historicizam o ser humano por meio das respostas promovidas. Ora, sua fé passa a ser uma modulação de seu ser histórico e, por isso, recebe as marcas do eixo espaçotemporal onde

\footnotetext{
34 GIRARD, René. O bode expiatório. São Paulo: Paulus, 2004.

35 GIRARD, René. A violência e o sagrado, São Paulo: Paz e Terra, 1990. p. 11-54.

36 ALVES, Rubem. Por uma teologia da libertação. Juiz de Fora: Recriar; São Paulo: Siano, 2019. p. 48.
} 
é exercida, assim como o próprio exercício da fé assume a possibilidade de proporcionar mobilidades históricas na condição humana e em seu mundo. Se as condições históricas são, de início, opressoras, então os modos de resposta humana ao mundo não se equivalem. Há modos que ratificam e reiteram formas históricas de opressão, assim como há outras que intencionam promover a superação dessas condições de desumanização da condição humana no mundo. Dessas possibilidades nasce a esperança como conceito-chave de produção de um futuro qualitativamente alternativo em meio a condições histórico-mundanas de desumanização. Esse futuro é índice de liberdade, que não se confunde, nesse caso, com livre-arbítrio. A liberdade é um processo dialético que passa necessariamente pela negação do elemento negativo que oprime a condição humana.

O novo não é obtido diretamente: o velho resiste ao novo e a ele se opõe. Em consequência, o Sim que a liberdade endereça ao novo torna-se histórico tão só através e para além do Não com o qual ela confronta, resiste e sobrepuja o poder do velho que pretende se perpetuar, abortando o novo. ${ }^{37}$

Assim, a liberdade consiste no jogo de não e sim, de recusa das condições histórico-mundanas de opressão e de afirmação criadora de formas humanizadoras de ser no e com o mundo. A esperança é, nesse caso, o horizonte de criação de futuro, por meio da dialética da liberdade humana.

Alves assinala que o momento da dialética da liberdade que visa negar o negativo é o momento que enfrenta a teopatia, como anteriormente assinalado. É que o negativo na história tem como signo primário o sofrimento que nasce da injustiça e avilta a vida na Terra. Ao se apropriar da relação bíblica entre o Deus de Israel e a história de seu povo, Alves entende que esse Deus está visceralmente relacionado com as metamorfoses da condição humana, sobretudo se levarmos em consideração que o Deus de Israel ouve o clamor nascido das dores do povo, dores essas que são efeitos da injustiça humana. Por isso o Deus bíblico é Deus sofredor. Ele não esquece as dores da injustiça. Essa memória divina do sofrimento não é fonte de ressentimento, mas de recusa das realidades injustas do presente e da exigência de criação de futuro. Nas palavras paradigmáticas de Alves:

O escravo pode esquecer seu sofrimento, mas não Deus. Deus é Deus sofredor, o Deus que jamais permite que as dores da história sejam ignoradas e curadas pelo poder hipnótico da política da preservação. Porque Deus, como presença do futuro, é um Deus na história, e já que sua esperança na história é sempre resistida pelos poderes do velho, Deus é um Deus que sofre. Não há teodiceia possível para aquilo que é, através de referências a Deus. Deus não é uma explicação para as dores do mundo. Pelo contrário: consiste no poder permanente que nega a justiça e o direito do sofrimento na história, sendo ele próprio o Deus que sofre, permanecendo o Servo Sofredor (doulos - Fp 2:7) (38 $^{3}$.

${ }_{37}$ ALVES, 2019, p. 169.

38 ALVES, 2019, p. 183. 
Aqui está a questão mais relevante: Deus sofre, porém recusa as condições históricas do sofrimento. Dessa forma, o fato de Deus não aceitar as condições de opressão que o fazem sofrer não significa que ele irá mágica ou causalmente modificar o curso do mundo. Antes, a graça transformadora de Deus leva o ser humano a atuar segundo possibilidades de libertação e de criação de liberdade. Assim como no registro agostiniano, a graça não suplanta ou suprime a "natureza", ou seja, a ação divina não se dá sem o engajamento humano pela promoção da humanização do mundo. A teopatia, no regime discursivo alvesiano, não transforma somente Deus em vítima, mas leva Deus a dizer não à opressão e desumanização do mundo. É exatamente esse "não" que nos interessa. Que "não" é esse? Certamente, não se trata do "não" que condiciona todo modo de ser ressentido, que Nietzsche considerou, em Para a genealogia da moral, como instituidor de valores escravos. ${ }^{39} \mathrm{O}$ "não" assinalado por Alves, inscrito na dialética da liberdade, é condição de possibilidade dos "sins" instituidores de liberdade. Por esse motivo entendemos que os "nãos" envolvidos na promoção da liberdade se identificam com o conceito de revolta, cujos contornos devem ser sinteticamente caracterizados a seguir.

Toda revolta se inicia com um "dizer não"; porém nem todo "dizer não" pode ser identificado com a revolta. Por um lado, a revolta é uma recusa, a "recusa a ser o que é" ${ }^{40}$. Por outro, a recusa é um caminho para se criar condições outras de vida que aquelas que possibilitaram o surgimento da própria revolta. Revoltar-se é implicar-se na tarefa de transformar o solo histórico em que a própria revolta nasceu. Mas qual o sentido da revolta? Ouçamos Camus:

A revolta nasce do espetáculo da desrazão diante de uma condição injusta e incompreensível. Mas seu ímpeto cego reivindica a ordem no meio do caos e a unidade no próprio seio daquilo que foge e desaparece. A revolta clama, ela exige, ela quer que o escândalo termine e que se fixe finalmente aquilo que até então se escrevia sem trégua sobre o mar. Sua preocupação é transformar ${ }^{41}$.

Que se atente, antes de tudo, para a relação entre injustiça, desrazão e incompreensão. A revolta só é possível quando o ser humano experimenta o absurdo da injustiça, sua desrazão, sua incompreensibilidade e, por isso mesmo, desnaturaliza sua perpetuação. Tendo experimentado o absurdo da injustiça, nasce a possibilidade da revolta. Por meio dela é necessário produzir sentido, fazer-ter-sentido uma vida marcada pelo absurdo da injustiça e de tudo que dela decorre. Acabar com o escândalo da injustiça, dos sofrimentos que nascem da injustiça, exige a criação transformadora de condições justas em que viver tenha efetivamente sentido. Por esse motivo se deve dizer que "a ordem no meio do caos e a unidade no seio daquilo que foge e desaparece" nada têm a ver com qualquer tipo de medida metafísica de sustentação do mundo. Ordem e unidade são, em verdade, ordenação e unificação da condição humana em seu mundo, ou seja,

\footnotetext{
39 NIETZSCHE, Friedrich. Genealogia da moral. São Paulo: Civilização Brasileira, 2000. I, §10.

40 CAMUS, Albert. O homem revoltado. Rio de Janeiro: Record, 1999. p. 21-22.

${ }^{41}$ CAMUS, 1999, p. 21.
} 
resultam de estratégias de criação de sentido social, político e existencial para além do absurdo da injustiça que se naturaliza na estruturação da (co)existência humana.

O sentido último da revolta aparece quando o caráter transformador do "não", sempre acompanhado por um "sim criador", deixa vir a lume um elemento da condição humana que vigora como fim em si mesmo. Ainda operacionalizando o pensamento camusiano, dizemos que a negação inerente à revolta possui como finalidade afirmar a dignidade, ou seja, o elemento inegociável da condição humana, que se poderia universalizar de modo não metafísico na noção de dignidade humana, mesmo que Camus não a usasse. ${ }^{42}$ Assim, a revolta nunca é individualista, por mais que seja realizada por indivíduos. Nela, está implicada a dignidade de seres humanos singulares cujas vidas não podem ser submetidas a condições de aviltamento. Melhor ainda: "Na revolta, o homem se transcende no outro, e, desse ponto de vista, a solidariedade humana é metafísica" ${ }^{43}$. É nesse sentido que a revolta não se identifica com a revolução. Essa, segundo Camus, operacionaliza ideais abstratos de humanidade e de justiça, o que permite submeter violentamente seres humanos, para que os valores nascidos dessa abstração sejam implementados na história. A revolta, de outra forma, submete a universalidade abstrata à singularidade humana. Por isso ela não possui fins absolutos, pois a cada vez se afirma contra o absurdo da injustiça e a favor da dignidade universal da singularidade humana. É essa noção de revolta que deve nos orientar no que estamos a chamar de teorevolta.

Devido aos limites deste artigo, assinalamos que a teorevolta possui ao menos dois sentidos: a) a revolta contra o Deus das teodiceias; e b) a revolta como dinâmica simultaneamente humana e divina de transformação criadora dos sofrimentos e males em geral, sobretudo daqueles vinculados às práticas de injustiça. Por isso um dos focos centrais da teorevolta é o que a tradição chamou de iniquidade, agora ressignificada à luz da ideia segundo a qual a injustiça naturalizada e sobretudo os sofrimentos que dela decorrem formam o horizonte do mysterium iniquitatis. O primeiro sentido está presente, por exemplo, nas palavras do já mencionado Salmo 22, reproduzidas por Jesus na iniquidade da cruz: Meu Deus, meu Deus, por que me abandonaste? (Mc 15.34). O verso 37 diz: E, Jesus, dando um grande brado, expirou (Mc 15.37). Naquele momento, diz o verso seguinte, o véu do Templo se rasgou. Há, certamente, uma história rica e consolidada de interpretação desse texto. Não é nossa intenção tematizá-la. Devemos ousar a compreensão segundo a qual a revolta é um possível horizonte hermenêutico dentro do qual o grito de Jesus e sua indignação diante do abandono de Deus podem fazer sentido. Jesus grita contra o Deus separado pelo véu do templo, pela interposição entre aparelho religioso e seu "objeto de culto", aquele mesmo que Jó, após um percurso doloroso, disse ter conhecido somente "por ouvir dizer" (Jó 42.5). Esse Deus, capturado pelo aparato da teodiceia, mesmo antes do surgimento dessa palavra e dos conceitos por ela operacionalizados, é o Deus contra o qual se volta Jesus na cruz. Somente um Deus indiferente às cruzes pode se fazer

${ }^{42}$ CAMUS, 1999, cap. I.

${ }^{43}$ CAMUS, 1999, p. 29. 
ausente no sofrimento da injustiça. Na cruz, Jesus se revolta contra o Deus que se ausenta do sofrimento nascido da injustiça. Porém é preciso levar em conta que a resposta teopática que diz estar o Pai e o Espírito Santo sentindo a dor do Filho na cruz não dá conta do sem-sentido, do absurdo da injustiça. Antes, é preciso ler também no grito de Jesus a revolta diante do Deus que se faz vítima da injustiça e que resume sua divindade à impotência que aí se apresenta. O grito de Jesus é a manifestação da impossibilidade de conferir sentido ao absurdo da iniquidade. Deus não pode se satisfazer com sua simples inocência diante da iniquidade. Deus só pode ser divino se se faz revolta contra a iniquidade. O mal exige o grito da revolta e a ira que diz "não" porque deseja o "sim".

O segundo sentido da teorevolta diz que a revolta é um modo de ser tanto de Deus quanto do ser humano, quando ambos, conjuntamente, se deparam com o mysterium iniquitatis. Vejamos, novamente, Jesus na cruz. Para além da vítima sacrifical , que na abordagem de Girard preserva a sacralização e legitimação da violência entendida como a lógica que atravessa e condiciona o tecido social em meio ao qual se manifesta a guerra de todos contra todos (homo lupus homini), Jesus não se resume a ser o "cordeiro de Deus", expressão que justifica religiosamente o assassinato por ele sofrido na cruz e o sublima na ideia de morte vicária. Jesus grita na cruz porque não quer ser vítima sacrifical; não quer ser bode expiatório; não quer conectar a humanidade pecadora com o Deus absconditus dos altos céus, divindade transcendente e ontologicamente ausente/indiferente. Em Jesus, divindade e humanidade se articulam na revolta contra a divindade e a humanidade que promovem, se abstêm de ou se conformam à iniquidade. Na cruz, o mal não é compreendido, não é explicado, não é somente sentido; ele é objeto de revolta. Em Jesus, Deus e humanidade se revelam contra o Deus e a humanidade da indiferença à iniquidade ou tragados pela iniquidade sob a forma da vítima absolutamente impotente. O grito de Jesus na cruz é a afirmação da indignação com e da ira/raiva simultaneamente humana e divina em relação à iniquidade. Nesse sentido, não seria a ressurreição a face afirmativa ou criadora da revolta de Jesus na cruz? Se for, então, ressuscitar é um ato deicida e antropocida: aniquila toda divindade que nasce da teodiceia e/ou que não se revolta contra a iniquidade, além de aniquilar qualquer tipo de humanidade que não faça o mesmo. Por esse motivo, na teorevolta, Deus e ser humano não negociam a dignidade.

É necessário responder novamente a questão: onde estava Deus nas vítimas dos campos de concentração, das balas "perdidas", dos genocídios contemporâneos, da necropolítica, do machismo, do racismo etc.? Talvez três respostas se façam obrigatórias: 1) Ele está morrendo com as vítimas da injustiça. 2) Ele está gritando de revolta com elas, nelas e por causa delas em meio à agonia. 3) Ele está ressuscitando nos/as sobreviventes, que inventam "nãos" e "sins", para que a iniquidade não seja a palavra final da história. Basta perguntar: onde estava Deus nos quase oito minutos de sufocamento de George Floyd? Ele estava agonizando com ele; estava gritando "I can't breathe" [Não consigo respirar] naquela cruz e ressuscitou em todos e todas que saíram às ruas, em todo planeta, para dizer: "Chega, o racismo acabou! Black lives matter!". Sem a divina revolta humana e a humanizadora revolta divina, as teodiceias e teopatias, consciente ou inconscientemente, sempre legitimarão a iniquidade. 


\section{Conclusão}

O caminho seguido no presente estudo identificou limites nos regimes discursivos teodiceicos e teopáticos, no que concerne à compreensão teológica do mal em meio ao quadro atual pandêmico. Nesse sentido, toda teodiceia é um tipo de estratégia discursiva de desoneração do divino quanto à livre produção do mal no mundo, o que passa a ser atribuído ao livre-arbítrio humano. Por outro lado, o pressuposto ontológico das teodiceias é a imunidade de Deus em relação à presença do mal na criação. Se isso explica as condições do mal no mundo e a culpabilidade humana em relação à maior parte das invenções dos males na criação, parece não dar conta dos absurdos ocorridos nos campos de concentração nazistas e em outros modos congêneres de destruição em massa de seres humanos e das demais criaturas. Daí a importância capital dos discursos judaico-cristãos teopáticos, que passam a implicar Deus no curso da história e no destino da criação.

Se um dos pilares ontológicos das teodiceias sempre foi a ideia de onipotência divina (conjugada com o conceito de imutabilidade), com as teopatias esse horizonte compreensivo se desloca: Deus possui vulnerabilidade e o destino dos seres humanos e da totalidade da criação diz respeito essencialmente ao seu ser. Deus não somente afeta a criação com a sua graça - ele é por ela afetada. Por isso Deus sofre, Deus se alegra, Deus chora, Deus ama, Deus celebra, ou seja, apesar da linguagem ser claramente antropomórfica, as teopatias assinalam o envolvimento do ser divino com o destino da finitude de toda criatura, sobretudo as criaturas humanas. Daí a assertiva: nos campos de concentração, nos genocídios de toda ordem, nas mulheres violentadas pela lógica do machismo, nos racismos mais diversos, Deus está morrendo. Ora, como mostrado anteriormente, esse discurso, apesar de pertinente e poderoso, é limitado. Retirar de Deus sua indiferença ontológica e transformá-lo em vítima não dá conta da iniquidade, esse tipo de mal que irrompe da naturalização da injustiça. Se a recondução de Deus ao lugar de vítima da injustiça fosse a solução da iniquidade, então o assassinato pelo assassinato, o genocídio pelo genocídio, o estupro pelo estupro, o racismo pelo racismo seriam, por si sós, pelo simples fato de aniquilarem vidas, a própria resistência aos males que produzem. A simples afirmação da impotência de Deus despotencializa formas de resistência à iniquidade.

\section{Referências}

AGOSTINHO, Santo. Obras completas. Madrid: BAC, 1957-1986. O livre-arbitrio. Trad. Ir. Nair de Assis Oliveira. São Paulo: Paulus, 1995. Solilóquios/A vida feliz. Trad. Ir. Nair de Assis Oliveira São Paulo: Paulus, 1998. . Confissões. Lisboa: Imprensa Nacional Casa da moeda, 2004. - A natureza do bem. Rio de Janeiro: Sétimo Selo, 2006. A doutrina cristã. Trad. Ir. Nair de Assis Oliveira. São Paulo: Paulus, 2007.

$\overline{\mathrm{ALVES}}$, Rubem. Por uma teologia da libertação. Juiz de Fora: Recriar; São Paulo: Siano, 2019. AQUINO, Santo Tomás de. Sobre o mal. Rio de Janeiro: Sétimo Selo, 2005.

ALMEIDA, Edson Fernando de. Do viver apático ao viver simpático: sofrimento e morte. São Paulo: Loyola, 2006. 
BIBLIA SAGRADA. São Paulo: SBB, 1993.

CABRAL, Alexandre Marques. "Hans Jonas, gnosticismo e a questão de Deus: entre redenção da naturezaecompromissoético". Numen: revista de estudos e pesquisa da religião, JuizdeFora, v. 18, n. 1,2015. CAMUS, Albert. O homem revoltado. Rio de Janeiro: Record, 1999.

GIRARD, René. A violência e o sagrado. São Paulo: Paz e Terra, 1990. . O bode expiatório. São Paulo: Paulus, 2004.

. O bode expiatório e Deus. Covilhã: LusoSofia, 2008.

HEIDEGGER, Martin. Identidade e diferença. São Paulo: Abril Cultural, 1973. (Coleção Os pensadores).

HESCHEL, Abraham, J. The Prophets. New York: Harper Collins, 2001.

JONAS, Hans. Pensar sobre Dios y otros ensayos. Barcelona: Herder, 1998. O princípio vida. Petrópolis: Vozes, 2004.

Matéria, espirito e criação. Petrópolis: Vozes, 2010.

KUSCHEL, Karl-Joseph. Teodiceia e Antropodiceia: O mal na teologia depois de Auschwitz. IHU ONLINE, edição 438, março de 2014. Disponível em: <http://www.ihuonline.unisinos.br/ artigo/5400-karl-josef-kuschel-4>.

METZ, Johann Baptist. Memoria passionis: una evocación provocadora en una sociedad pluralista. Santander: Sal e Terra, 2007.

MOLTMANN, Jürgen. Paixão pela vida. São Paulo: Aste, 1978.

Trindade e Reino de Deus: uma contribuição para a teologia. Petrópolis: Vozes, 2000. . Experiências de reflexão teológica: Caminhos e formas da teologia cristã. São Leopoldo:

Unisinos, 2004.

. O Deus crucificado: a cruz de Cristo como base e crítica da teologia cristã. Santo André:

Academia cristã, 2011.

NIETZSCHE, Friedrich. Genealogia da moral. São Paulo: Civilização Brasileira, 2000.

QUEIRUGA, Andrés Torres. Repensar o mal: da ponerologia à teodiceia. São Paulo: Paulinas, 2011.

RICOEUR, Paul. O mal: um desafio à filosofia e teologia. Campinas: Papirus, 1988.

SÖLLE, Dorothee. Sofrimento. Petrópolis: Vozes, 2007.

UNAMUNO, Miguel. Do sentimento trágico da vida. São Paulo: Martins Fontes, 1996.

ZIZEK, Slavoj; GUNJEVIC, Boris. O sofrimento de Deus: inversões do Apocalipse. Belo Horizonte: Autêntica, 2015.

Site acessado:

$<$ https://veja.abril.com.br/religiao/edir-macedo-dissemina-informacoes-falsas-e-atribui-coronavirus-a-satanas>. Acesso em: 16 jun. 2020. 